Article

\title{
'Interrupted' Landscapes: Post-Earthquake Reconstruction in between Urban Renewal and Social Identity of Local Communities
}

\author{
Matteo Clemente ${ }^{1, *}$ (D) and Luca Salvati ${ }^{2}$ \\ 1 Department of Architecture and Projects, Sapienza University of Rome, Via Flaminia 359, I-00196 Rome, Italy \\ 2 Research Centre for Forestry, Council for Agricultural Research and Economics (CREA), \\ Viale S. Margherita 80, I-52100 Arezzo, Italy; luca.salvati@crea.gov.it \\ * Correspondence: matteo.clemente@uniroma1.it; Tel.: +39-335-7610690
}

Received: 23 October 2017; Accepted: 1 November 2017; Published: 3 November 2017

\begin{abstract}
The present study deals with the topic of post-seismic reconstruction focusing on landscape and social issues. Sustainable reconstruction requires a connection between the physical context of a given territory and the immaterial (historical, cultural, productive) values that constitute the place's identity. In this perspective, those places that have been destroyed by severe earthquakes or other disasters could be labelled as "interrupted landscapes", meaning a drastic break in the individual stories attaching the people to their own territory, as well as an abrupt alteration of the continuous process by which people attribute a sense to their own territory. The study discusses selected cases of post-earthquake reconstruction in Italy, providing an overview of different visions for development of the new towns, that oscillate between two contrasting approaches: the "new town" model, implying the construction of a new town off-site and the "in loco" model. Looking for the reasons for failures of the new town model reconstruction, the study also debates the social dimension of urban landscapes, reflecting upon the notion of 'collective identity' connecting place attachment to cultural heritage. These issues were finally considered when defining strategic guidelines for sustainable urban reconstruction promoting place identity and preserving the intimate characteristics of the affected landscapes. Governance actions were defined along with sustainability strategies based on the investigated case studies, outlining a series of best practices that may promote the permanent involvement of local communities.
\end{abstract}

Keywords: post-seismic reconstructions; cultural identity; resilient community; landscape enhancement

\section{Introduction}

Earthquakes, flooding, landslides, and other natural disasters have shaped the history of the Italian territory, with reconstruction processes producing different outcomes. Guidoboni and Valensise [1] portray a detailed picture of post-earthquake reconstructions in Italy up to the mid-2010s. For example, post-seismic reconstructions have been carried out since the Middle Ages, in more than 4800 cases in Italy, with seismic disasters occurring, on average, every $4-5$ years in the last 150 years, causing nearly 150,000 casualties. These victims are added to the 6000 deaths caused by landslides (nearly 2800 cases) and those caused by flooding, which have happened all over the Italian territory. The annual cost of such disasters exceeds, on average, is 5.5 billion Euros, increasing progressively, as much as the ability to predict and reduce disasters has improved, thanks to significant advancements in scientific and technical knowledge [2].

The recent destructive earthquake which occurred in the Apennine mountain district, central Italy (2016) a few years following the earthquake of L'Aquila, Central Italy (2009), causing the collapse of 
many towns belonging to four administrative Italian regions (Umbria, Marche, Abruzzo, and Latium) has once again put in the foreground the complex issue of reconstruction of rural villages in Italy.

The frequency and impact of those seismic events on middle/small towns with historical urban fabric, architectural heritage, and cultural traditions, requires careful reflection regarding the theme of reconstruction. Therefore, the comparison between different case studies could be useful to define guidelines for facing future post-seismic scenarios and providing an improvement for the past reconstructed places.

Being partly or totally destroyed by severe earthquakes, these places can be regarded as "interrupted landscapes". This notion, as stated in this research, incorporates all meanings of the term 'landscapes', connecting the physical reality of those places with immaterial values (historical, cultural, productive, artistic, food/wine related goods) that constitute the identity of such territories, being the result of long-term anthropogenic transformations and latent socioeconomic processes. These places exist in the daily life of the local people, and in the social practices of inhabitants and visitors who give them sense and social significance, producing, at the same time, new meanings and interpretations of rural landscapes, shaping multiple identities linked to collective and individual perceptions of places. While people have made these places authentic and livable through their individual experiences, landscapes affected by traumatic events, such as severe earthquakes or other natural disasters, display a progressive disruption of individual and collective narratives, representing a social fracture difficult to overcome.

Post-seismic reconstructions may reproduce a destroyed building where it was and how it was, but cannot recreate the authenticity and the meaning of a place over the same time. 'Simulacrum' imitations of reality, typical of rapid post-seismic interventions, may confer to the affected landscapes an image which would be very different from the original one, altering the relationship with local communities.

The present study illustrates the notion of "interrupted landscapes" from selected narratives of post-seismic experiences in Italy, investigating the relationship between citizens and their own territories that could determine the success or failure of the reconstruction program. The discussion highlights that the main objective of a sustainable reconstruction is to promote territorial livability for local communities and contribute to the socioeconomic redevelopment of destroyed areas. In this perspective, social cohesion and cultural landscapes may be considered as driving forces for a sustainable development after a traumatic event [3].

\section{Analysis of Selected Case Studies}

The debate over post-seismic reconstruction in Italy has oscillated between two main ideas, based on off-site or on-site interventions. Off-site approaches are based on the construction of 'new towns' located in the proximity of the old town, where it is safer and where devices for the improvement of safety level can be employed. On-site approaches, supporting the slogan of "where it was, as it was", which was used for the first time by the major of Venice during the aftermath of the collapse of the San Marco Bell Tower, Venice in 1902 (Figure 1), and is repeated like a mantra in Italy during the aftermath of every earthquake. The Venice Bell Tower collapsed because of the deterioration of the bricks walls and the Venetians wanted to rebuilt it "in loco", like a copy of the ancient one, against the opinion of many architects of that time, who proposed a new design.

The present study is based on a literature review and examines the most relevant post-seismic reconstruction which occurred in Italy, starting from the historical case of reconstruction after the earthquake of 1693 in Sicily, up to the more recent earthquake of L'Aquila (2009). Set .in a chronological sequence, the case studies have been divided into two sections of on-site and off-site reconstructions. The case of Cavallerizzo (Calabria, 2005) which is a post-landslide reconstruction, was also discussed because it is an emblematic example of a new town rebuilt in recent years. Case studies have also been chosen from various Italian areas in order to observe a vast range of socioeconomic contexts characterizing post-seismic reconstruction. From affluent and economically-dynamic areas of 
northern Italy (e.g., Friuli 1976, Emilia-Romagna 2012) to rural districts in central Italy (Umbria 1997, Abruzzo 2009, Latium 2016) and economically-disadvantaged areas in southern Italy (Campania 1980).

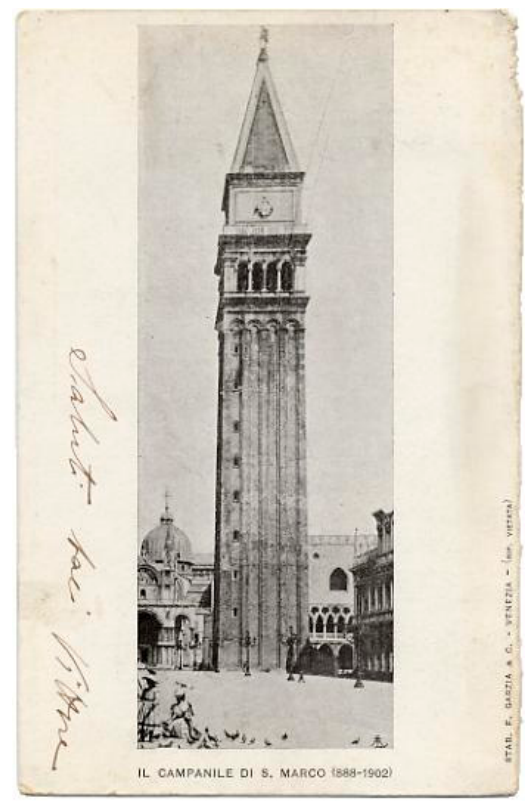

(a)

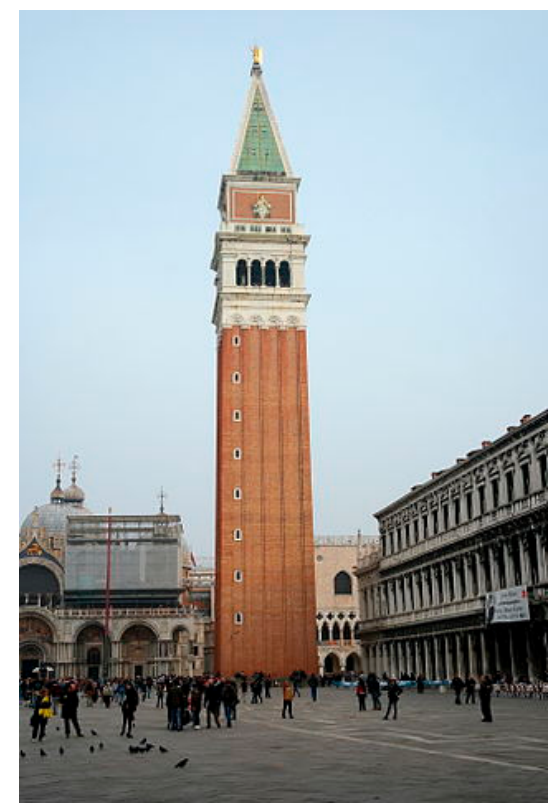

(b)

Figure 1. San Marco Bell Tower, Venice: (a) before the collapse in a postcard of 1902; (b) after the reconstruction (1912), photo by Luca Aless, 2015, creative commons.

The Italian experience in post-seismic reconstructions provides an interesting overview of the two approaches mentioned above, shedding light on the main implications for sustainable reconstruction programs, in the light of preserving 'place identity' and social cohesion of local communities.

\subsection{The 'New Town' Model}

The idea of "new towns" in post-seismic reconstruction dates back to the last century. Indeed, after the catastrophic earthquake of 1693 that struck around 70 towns and villages in Eastern Sicily_among which included Catania, Siracusa, Scicli, and Ragusa-causing more than 60,000 casualties, the Spanish government decided to rebuild those villages according to "ideal types of cities" as suggested by the reconstruction of Grammichele (Catania). Grammichele's cities have a hexagonal shape and radiocentric structure inspired by Renaissance urban design, which features a spiderweb-like design (Figure 2), much different from the original Medieval urban structure stratified in time (Avola and Occhiola) which had been destroyed by an earthquake. A public debate arose for Noto in a public plaza, just like what might occur nowadays, as to whether the city should be reconstructed on the old village, or on the plain, in a safer place, following urban planning criteria based on the idea of a new town. At the time, the majority of the voters, artisans, and farmers voted to stay in the old village site, near their fields. However, the dominant noble oligarchy prevailed, and they decreed the birth of a new city based on new urban design [4,5].

Most of the city was rebuilt on site on the ruins of the old village, but following a completely new street plan, elaborated with the technical collaboration of military engineer Carlos de Grunembergh, a military fort design expert from the Netherlands, nominated by the Commissioner for Reconstruction.

This extensive reconstruction of the affected cities, thanks to an enormous collective effort involving the cooperation of all Sicilian social levels at the time (including the Spanish government, the feudal nobility, the clergy, the urban communities) gave birth to the Sicilian Baroque style (namely the 'Barocco Ibleo'), recognized as an extraordinary local declination of Italian baroque [6]. 


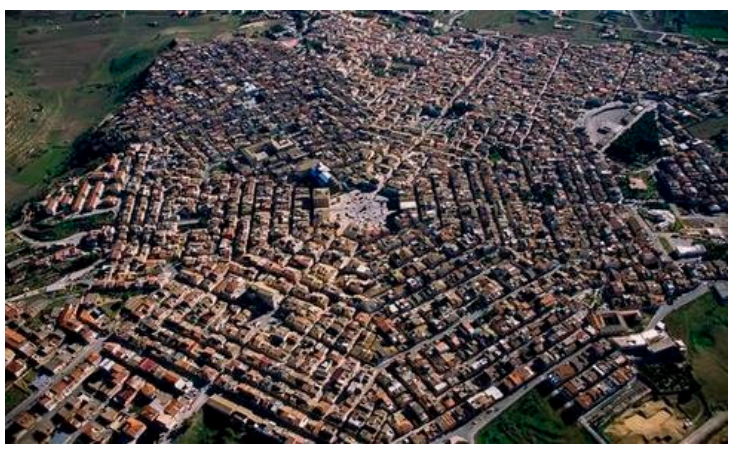

(a)

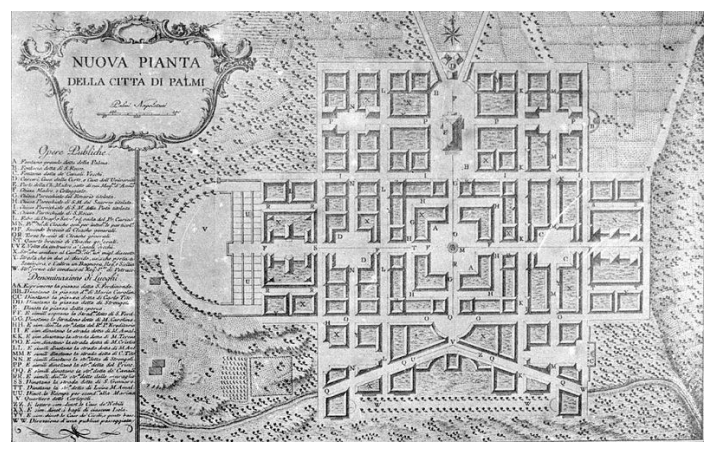

(b)

Figure 2. (a) Grammichele (Catania) rebuilt off-site as a city founded after the 1693 earthquake. (b) Palmi Urban Plan (Calabria), designed by Giovanni Battista de Cosiron following the 1783 earthquake.

New towns were also built in the Calabria region in the aftermath of the sequence of catastrophic earthquakes in 1783, such as Filadelfia, constructed in a new place called "Piano della Groma" close to the ancient village of Castelmonardo, with the consensus between the Neapolitan planners and the local community [7]. Inspired to the plan of an "ideal city" with a squared mesh, a symmetrical design of residential buildings and a large rectangular square acting as the town's core, it was built in a form completely different from the destroyed village. The reconstruction of entire cities, such as Reggio Calabria, Messina, Mileto, and Palmi, was carried out according to completely new urban planning rules which could be considered as an attempt to establish norms to reduce seismic risk [8].

The most destructive earthquake of the last century occurred in Messina (Northeastern Sicily) and Reggio Calabria (Southern Calabria) in 1908, leaving more than 100,000 victims, and followed by a building reconstruction that had been planned as a typically-additive urban expansion process. Messina, a city with a consolidated maritime tradition, doubled its extension based on guidelines of a new Master Plan laid out by Luigi Borzi (Figure 3), who designed a completely new city with wide streets and a grid plan. The city was reconstructed with major safety criteria, providing an occasion for urban renewal and a new image of the city, with improvements that extended for much time to follow. The reconstruction of the block called "Palazzata", a majestic neoclassical building, known as the symbol of the city, had been realized between the 1930s and the 1950s by famous architects, such as Giuseppe Samonà, later underwent successive interventions and post-war alterations [9].

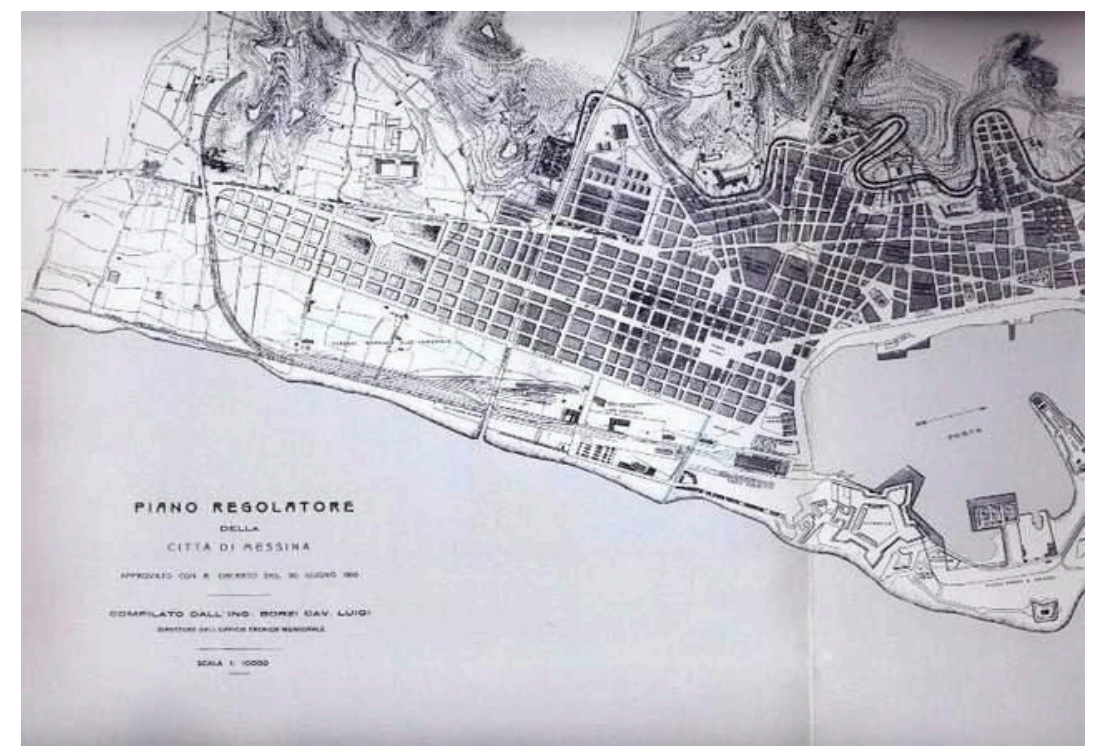

Figure 3. Messina urban plan with the northwestern zone urban expansion foreseen by Borzi in 1911. 
As far as the most recent earthquakes in Italian history are concerned, featuring eye-witness testimony by those who experienced them directly, an emblematic off-site reconstruction case was seen in the Belice basin (Sicily) in 1968. The Belice earthquake severely impacted a rural district experiencing a long-term economic crisis and social decay and the idea of abandoning the old villages was accepted quite quickly, without any protest from the local population [10]. In Gibellina, likely the most affected place in the area, post-earthquake reconstruction included the rebuilding of a new town, far from the old village, producing fragmented and "interrupted" urban landscapes considered exogenous to the place's tradition and social representation of the local communities [11,12]. In order to give a boost to the new city, local authorities engaged famous artists (Schifano, Pomodoro, Paladino, Burri) with the aim to contribute to architectonic projects looking for a new 'place identity' [13]. The only artist who refused to realize one of his works for the new city of Gibellina was Alberto Burri, who concentrated, instead, on a project of redesigning the old town's ruins: the "Grande Cretto" installation, where the paths of the streets became groves, which evoked a powerful image of the destroyed city (Figure 4).

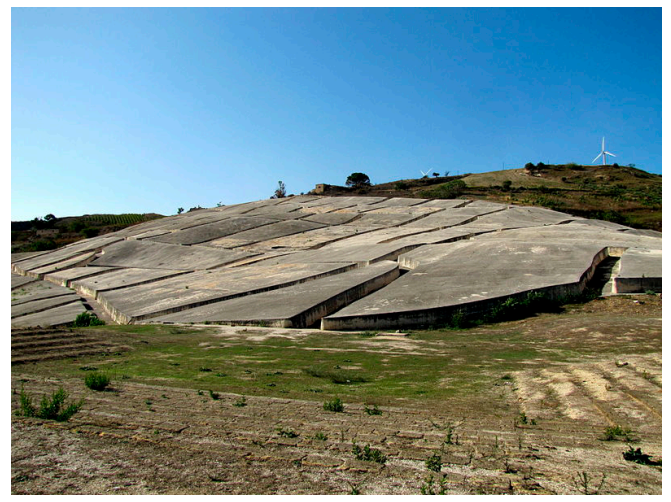

(a)

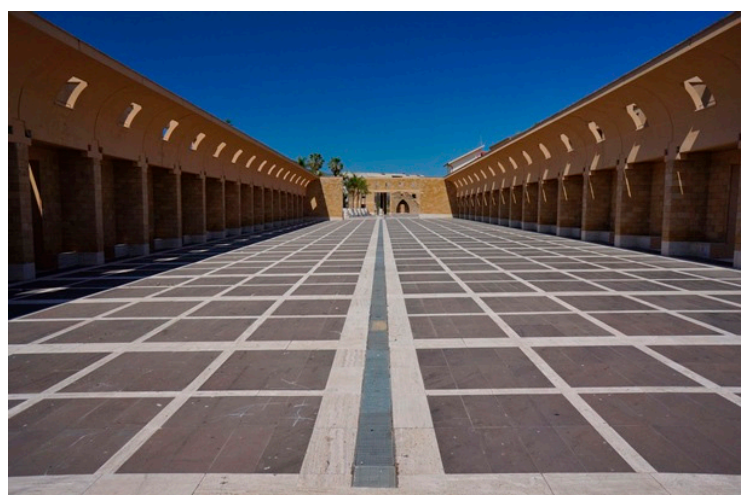

(b)

Figure 4. Gibellina: (a) 'Grande Cretto' by Alberto Burri in Gibellina Vecchia, Sicily (Creative Commons, photo by Fabio Rinnone, 2012); and (b) the plaza in the new town of Gibellina, project of Franco Purini and Laura Thermes, 1982-1990.

However, the attempt to reconstruct a new city on a "tabula rasa", despite the prestigious experts involved, transformed Gibellina into a museum-city, visited by tourists because of its artworks, but evidently less attractive for its inhabitants, leaving great squares by Franco Purini and Laura Thermes empty like deserts and without people, such as the ones represented by De Chirico or Sironi. The typology of the newly-constructed houses did not match the essential characteristics of the pristine site and were immediately rejected by the local citizens. The new town model was also proposed in the aftermath of the L'Aquila earthquake (2009) that brought the construction of new residential settlements physically separated (and morphologically distinct) from the affected city in a relatively short time: the so called "C.A.S.E. Project" [14].

L'Aquila is the capital of the Abruzzi Region (Central Italy), which had a population of ca. 70,000 before the earthquake. A city of medieval origins with a rich historical heritage and an urban fabric of great interest, which was completely destroyed by the earthquake. In the aftermath of the earthquake, the emergency management has been controversial, driven by the Prime Minister Silvio Berlusconi and centralized in the national Italian Civil Protection Department. This has replaced local response measures with national measures [15] in line with a top-down, paternalistic strategy that led to a significant scission within the local community, which saw, with prejudice, the actions taken by the Central Government [16].

As a first step of the post-earthquake reconstruction process, Temporary Housing Prefabs (MAPs) were built in the proximity of damaged centers along with new towns made up of Earthquake-proof 
Eco-compatible Housing Complexes (C.A.S.E.) (3). Overall, the C.A.S.E. project includes 184 buildings and 5736 residential flats at 19 sites around L'Aquila [17].

The C.A.S.E. project created urban landscapes formed by homogeneous building blocks lacking commercial services and those collective places that constituted the matrix of the social and relational system (Figure 5), altering the 'sense of community' of local inhabitants [18]. Beyond the technical and architectural issues, a specific issue arose from the individual stories and complaints of the resident people: the (increasing) sense of estrangement from the pristine landscape that may shape a "waiting community", whose unique desire is to go back to the old city [19], the only one they recognize as their own city and home [20]. Resident people have persistently asked for temporary wooden dwellings while waiting for the on-site reconstruction of the buildings [20,21].
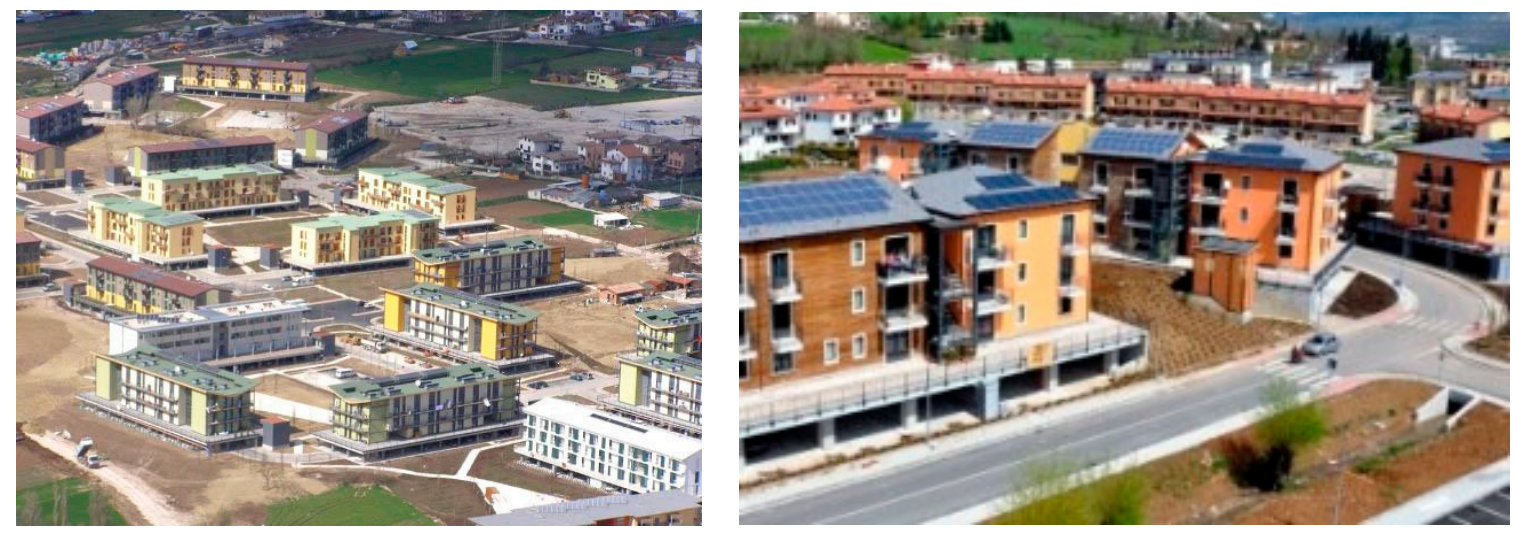

Figure 5. Aerial view of some blocks of the C.A.S.E. project in one of the "new towns" constructed in the aftermath of the 2009 L'Aquila earthquake.

In this sense, the "C.A.S.E Project" developed by the Italian Civil Defense in L'Aquila city has been considered a negative example for the effect on local communities and, currently, there has been an inversion tendency which is focusing reconstruction in the historic center.

The model of "founded city" in a nearby area has already been carried out by the Italian government for the reconstruction of the village of Cavallerizzo di Cerzeto, a Calabrian-Albanian community, destroyed by a landslide in 2005 (Figure 6). The "new town" built across from the old one, looks new, but aesthetically artificial, with small white houses, failing to reproduce the Albanian 'gijtonia' housing scheme typical of those places. Out of a total of 264 houses, only 85 resident households were recorded in 2015. This figure indicates an increasing tendency towards depopulation, in turn reflecting a latent protest of people who put this reconstruction project under serious dispute [22].
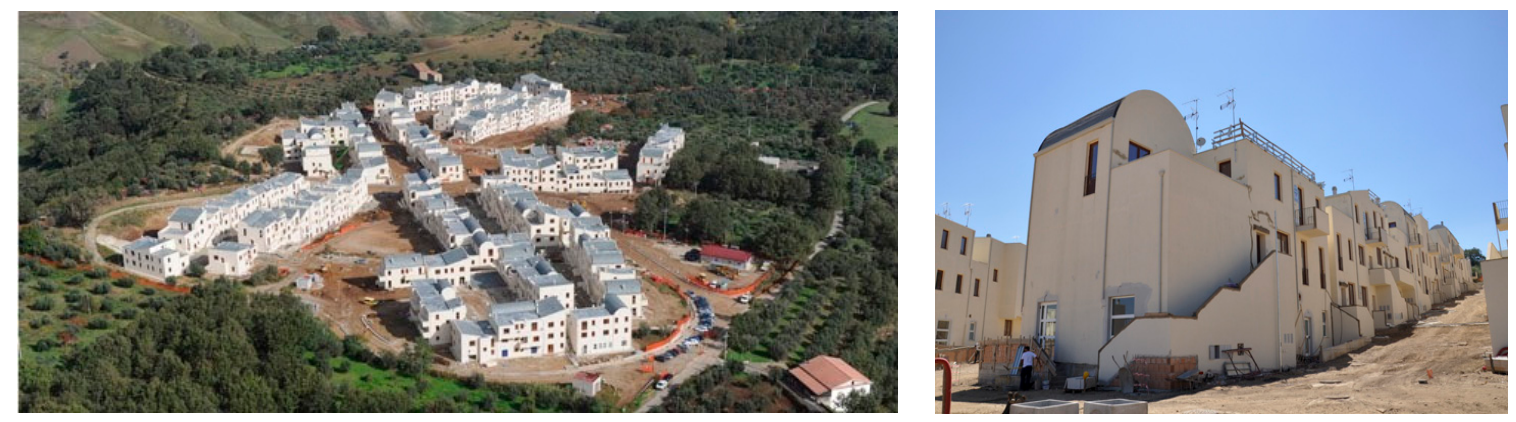

Figure 6. The new town of Cavallerizzo di Cerzeto (Calabria, Italy) destroyed by a landslide in 2005 and constructed in a nearby area (photos by the website of Italian Civil Protection). 
Alienation from the original place is a common perception also in settlements rebuilt exactly in the same place where they were destroyed, if the reconstruction project was disconnected from the needs of the resident population. This was the case of San Giuliano di Puglia, Southern Italy, where a severe earthquake (2002) caused the collapse of a school with 28 casualties. Rhetorical policies prevailed in this case over a correct planning for intervention through the realization of mainly unnecessary works. Rebuilding activities resulted in an oversized school next to a branch of the university, a sport hall, an Olympic pool, a museum, a laboratory, and an auditorium serving a village of approximately 1000 citizens. These outcomes result from reconstruction models fully disconnected from the local socioeconomic context, failing to attract inhabitants from neighboring places.

\subsection{The "Where It Was, as It Was" Model}

The model of reconstruction "where it was, as it was" has been differently adapted to local contexts affected by more or less severe earthquakes in Italy.

After the 1980 earthquake of Irpinia (between Basilicata and Campania Region), the on-site reconstruction based on "minimum intervention units" (according to the Law 457/1978 which introduced the Recovery Plan) [23,24], faded away because of the ineffective management of public funding and because of technical deficiencies of local agents [9]. The Irpinia earthquake seriously damaged more than one hundred towns and destroying hundreds of thousands dwellings. Although reconstruction funds were provided, too many projects spread out over a vast area left too many incomplete infrastructure works and many villages with half-constructed buildings.

Conversely, examples of virtuous building reconstruction are found in the experiences realized in Friuli Venezia Giulia, Northern Italy, after the 1976 earthquake. Here, post-seismic reconstruction not only followed the principle of "where it was, as it was", but was also capable of restoring the most relevant 'social attributes' characterizing the pristine settlement model, paying attention to the imminent characteristics of each site and adapting it to different local contexts and landscapes [25]. Particular attention was given to public spaces, rural traditions and conservation/promotion of cultural heritage. Many historical monuments had been carefully reconstructed [26,27], sometimes stone by stone, as it happened in the rural town of Gemona, Udine (Figure 7). At the same time, buildings that did not need to be preserved have been re-constructed in a different way, involving the wide participation of local communities in planning choices. Based on this experience, rebuilding does not necessarily mean preserving the old buildings, but also innovating according with the evolution of the scenarios and citizens' requests.
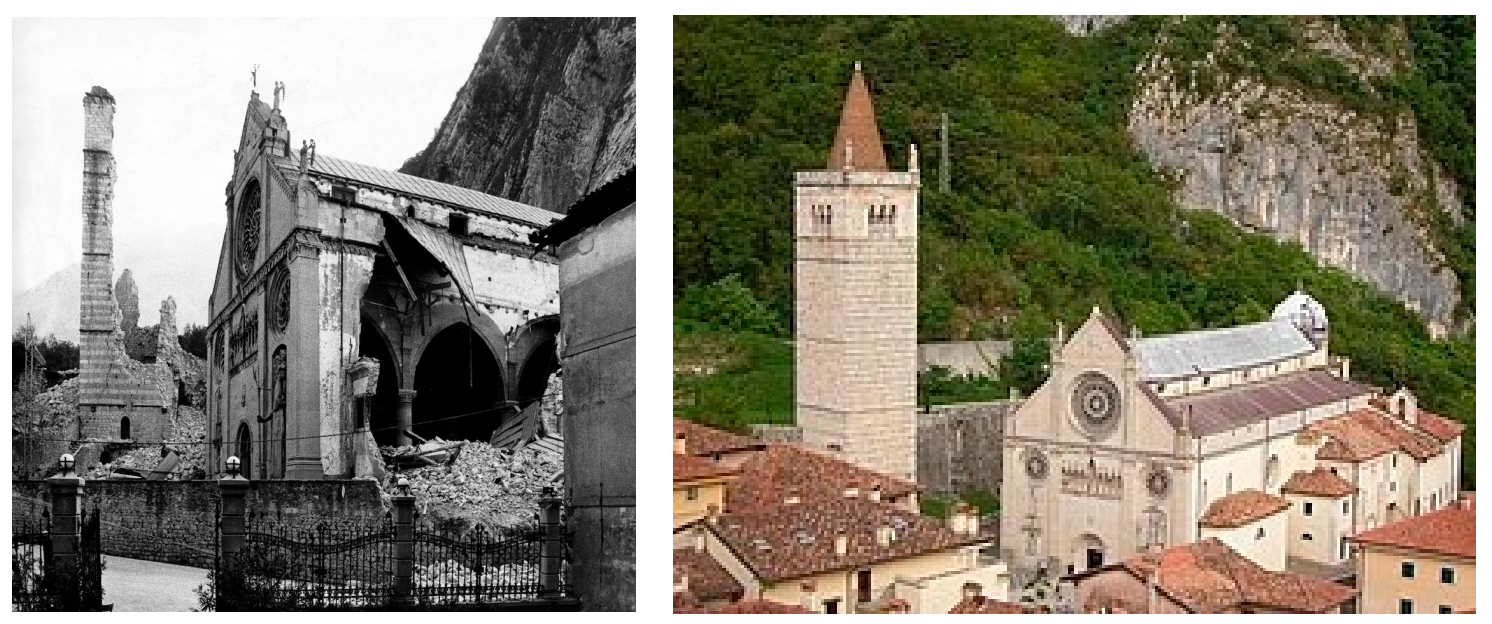

Figure 7. The Gemoma Dome, reconstructed stone by stone after the 1976 earthquake (photos by Wikipedia). 
In the case of Friuli, thanks to a wealthy socioeconomic context, the involvement in reconstruction works of enterprises and craftsmanship able to produce furnishings and building components, has contributed to the full integration of citizens in these activities. Therefore, the local enterprises already operating in the area took part in the socioeconomic upturn that came from the physical reconstruction of the affected places.

Even the reconstruction after the 1997 earthquake in Umbria and Marche (Central Italy), went through a flexible management based on earlier experiences, e.g., from the Friuli region. The vision for the partial reconstruction of the municipality of Foligno, a town close to Perugia, was to be rebuilt soon after and in a good way "where it was and as it was". After 15 years, most of the families affected by the earthquake went back to their houses. In this area, post-seismic reconstruction was primarily linked to depopulation of minor rural centers, with young people moving to major regional centers (Perugia, Terni) or to Rome, at least.

Reconstruction processes are always connected to local culture and assume different regional and local identities. Emilia Romagna, an affluent region with an economic base dominated by small and medium-size activities devoted to traditional and advanced industry, handicraft, and agriculture, is a representative example of this issue. A large part of the region was hit by a serious earthquake (2012) that destroyed a number of hangars and industrial installations. In response to this disaster, local and regional governments prioritized the reconstruction of factories and infrastructures with the aim to reduce the risk of a competitiveness decline in the affected district of Mirandola, one of the most productive and rich in Northern Italy.

\section{Discussion}

The case studies that we have compared in the preceding paragraph lead to make some other considerations about post-seismic reconstructions.

In the L'Aquila reconstruction case, which we have compared to the Cavallerizzo village or the San Giuliano of Puglia reconstructions, all characterized by a central management driven by political aims [2,15], it is demonstrated that the models imposed by central authorities without mediations with the local instances are destined to fail and will be rejected by the local citizens.

Top-down practices have been conducted in the aftermath of the 1980 earthquake in Campania and Basilicata. Even if based on the on-site reconstruction model, they have not been aligned with local necessities. These paternalistic and top-down strategies, adopting a 'command-and-control' approach that centralizes decisions, preserves the status quo and leads to the skewing of activities towards supply rather than demand [28].

On the other hand, we can observe spontaneous groups and associations of citizens emerging independently from formal institutions during the period of reconstruction following natural disasters [20,21], which promote an inclusive vision of disaster recovery rather than an elitist and top-down one $[29,30]$. In this sense, disaster resilience could be considered as a place-based process [31,32], enacted by grassroots groups that assume, together with the local institutions, the responsibility for reconstructing the area affected by a disaster, experiencing a spontaneous and autonomous way of taking action $[20,33,34]$.

In this perspective, after the earthquakes in Friuli (1976) and that of Umbria and Marche (1997), which can be considered good practices of post-seismic reconstruction, the government partially decentralized recovery at regional, municipality, and community levels, preserving most of the pre-existing spatial and socio-economic structures [35]. Particularly in Umbria a process of recovery and exploitation of small abandoned mountain villages has been engaged, promoting handicrafts, agricultural, and accommodation activities.

Additionally, in the case of the Sicily earthquake of 1968, the Italian government coupled reconstruction goals with the socioeconomic development in a paternalistic way, through the modernization, industrialization, and urbanization of a rural and 'underdeveloped' area [12]. Actually, from careful examination of the sources and testimony of the people involved, it emerges 
that many strategies were adopted to involve the local population. Gibellina Vecchia hosted theatrical events, local artisans' ceramics workshops were set up, and planning workshops involving students of the University of Palermo were organized. However, all of this is still not enough to restore vitality to those areas. Gibellina leads us to reflect on whether all projects developed without the participation of the people to whom the reconstruction is dedicated, based on imagined or abstract ideas and hypothesizing future beneficiaries based on overly optimistic previsions, are destined to failure.

The central aim of all reconstruction must, therefore, be the well-being of the inhabitants and their relation to the place, which, from a semiological perspective, must have three key elements: identity, relationship, and history.

The citizens who have survived destructive earthquakes undergo three phases of "estrangement" from their habitat: first they are deprived of their homes; then they are lodged in temporary structures where they end up remaining for years, finding social spaces, but still having as a reference point the former semi-destroyed nucleus [11]; and then the third phase in which the new towns or neighborhoods are completed and they move into them.

Several experiences of post-seismic reconstruction in Italy suggests that the most difficult part of healing is the division that lies between the reconstruction of the lost material heritage and the community that lives there, with the final objective being to prevent the progressive emigration of the citizens. Post-earthquake reconstruction, as revealed in some cases considered in this study, has sometimes conflicted with the identity of local communities, determining social fragmentation and radical fractures in the urban context, often resulting in the progressive abandonment of locally-inhabited places. The reconstruction processes, even within the operational concept of "where it was, as it was", involve different issues related to the authenticity of new artifacts and to the long-term social sustainability of architectonical interventions, going beyond specific prescriptions of building renovation and urban planning [36].

Reflections carried out in this study indicate that feasible and sustainable options for post-seismic reconstruction will benefit from a comprehensive analysis of local communities, place identity, and traditional settlements affected by earthquakes. Based on the individual stories of resident people, the post-seismic Italian reconstruction cases investigated in this paper first show the attachment of people to the original places. Environmental psychology went further into the issue dealing with the attachment to a given place [37]. Being described as a kind of sentimental relationship, the so called "topophilia" [38] refers to (i) the case where a place is identified, for example, with the childhood memory of someone, raising up positive feelings and emotions, and (ii) to the "sense of a place" which always foresees an acknowledgment of that place by someone, because that place reflects a particular (positive) meaning or perception.

Gasparini [39] defines the sense of belonging to a place in sociological terms, as it represents the acceptance of a local identity: thanks to that, local identity results straightened. Based on these findings, the concept of belonging is rather complicated, including the link between inhabitants and a physical place (a town, a house, a territory) that involves all sentimental, social, and relational components of a territory. Since the concept of "place attachment" involves the bi-univocal link between a local community and the "lived space" [40], the attachment to a site can be defined as a "sense of community", which has relevance once a territory is affected by disturbances and shocks, such as earthquakes and other natural disasters; only considering these aspects, and keeping human relationships alive, it would be possible to design a truly sustainable post-seismic reconstruction program.

Within this perspective, the notion of landscape assumes a latent relationship between humans and a given territory. The "territory" is the main palimpsest of the human action, where natural and anthropogenic dynamics take place; the "landscape" reflects the societal perception of such dynamics. In its double dimension of the "background" of social action and the "product" of the same human action [41], urban landscape is the main expression of local culture, since its construction is rooted in the socio-cultural values of a certain collectivity; but it is also the context of continuous 
semantic exchange between territory and local communities, who are inevitably conditioned by that socioeconomic context. In this sense, the landscape reflects the outcome of a precise local culture [36], as it is also a vehicle for cultural identity, being the apparent product of human interactions with its environment symbolic values preserved in a given place. The cultural identity of a landscape is determined through the process of historical sedimentation of all those signs to which humanity gave them significance: it deals with historical monuments, natural beauty, and artistic and literary works, as well as gastronomic specialties, events, and traditions. Cultural identity relies on values that are shared because of their contribution to create a social identity. The latter requires a conscious choice, an individual and collective interpretation that settles through people's histories.

Time plays an important role in the construction of cultural landscapes, as a physical context that might mean to serve as the repository of collective values. The time effect transforms the anthropological landscape into an aesthetic phenomenon [42]. This is exactly what happens within minor historical centers in central Italy, where settlement structure and the daily life's places take on a more aesthetic value representing the authenticity of those places. Post-seismic reconstruction projects that plan to restore or recover together place identity and pristine characteristics of rural landscapes are seen as an effective response for achieving a sustainable environment reducing, at the same time, the risk of consolidating social fractures in the 'interrupted' landscapes. By this perspective, since each place has many faces, many significances and, thus, many interpretations, place identity is a polysemic issue, and it cannot be defined through strict semantic categories. When it comes to places, towns, or landscapes, there are no univocal meanings, with no single and objective identity for a place. There are many identities, as much as perceived by the people, both by insiders and outsiders.

Shaping place identity is an ongoing process that does not happen within single individuals, but rather defines itself through the interactions with the community where they live [43]. In this perspective, identity appears as a narration process where each member of a local community tries to give consistency and continuity to their own existence, strengthening the relationship with the place and the social integration. Considering this relationship between people and places in the reconstruction's programs is relevant to achieve sustainable interventions that go beyond the physical recovery of the buildings, abstract from the place's identity and social representation of the local communities.

\section{Conclusions}

Landscapes interrupted by shocks and traumatic events generate a break in individual stories and a social fracture between places and local communities. On the basis of the above considerations, it can be understood how difficult it is to rebuild a territory, trying to re-establish the original state of the place and its social relationships, which cannot be resumed unless an ongoing process of narration and interpretation by the citizens themselves is kept alive in site. Rebuilding an identity "ex abrupto", without considering the gradual historical sedimentation in the social context, would lead to gentrification, fake identities as those typical of new towns, theme parks or outlet malls. Within this context, our contribution outlines the centrality of the 'landscape' concept. Rural landscapes and the respective local communities become 'the sick and the cared', the recipients of the reconstruction and the context basis for social cohesion and cooperation at the same time.

Taking into consideration the critical situations examined in case studies some resilient strategies emerge which can lead to a sustainable reconstruction aftermath of a traumatic event, first considering the community that lives in the affected places, then the buildings.

(i) It is important to actively involve the local communities in the rebuilding process. On one hand, grassroots groups emerging independently from formal institutions' needs to be supported, because they can play an important role in creating the sense of community. On the other hand, a participation strategy in terms of "territorial foresight" [44] needs to be activated. It is not only a matter of involving people or predicting the future; it is even more a practice which proposes an evolution of possible scenarios, based on the available resources and the potentialities of the 
territory, involving stakeholders, public institutions, and citizens that might strategically orient future choices. The community engagement, which also included in the recent case of Amatrice (2016) the organization of events with famous artists in the affected places, could maintain place attachment and social cohesion in the first period following the disaster. However, in the long run, the only way to prevent people from leaving the site is to favor the rebuilding of their own life, starting with their jobs, as the Friuli experience clearly demonstrates. This way inhabitants who are sentimentally attached to their homes can avoid the estrangement of abandoning their towns for other places without ever returning. In this perspective, the construction of a resilient community has to begin before a traumatic event, as a preventive strategy for risk mitigation and adaptation [45]. Therefore, prevention should not only provide the anti-seismic building refurbishment, but also include a more comprehensive strategy for sustainable local communities, along with social aspects and landscape preservation [46,47]. In this sense, landscape enhancement, as a strategy shared by the community before the traumatic event, can be, itself, the engine of social cooperation for rebuilding the community [44], and developing reaction strategies after an earthquake which would eventually lead to new socio-economic prosperity. Landscape diversity and place identity could represent the strength of each territory [48] to react to those changes and set up new prospects for the future.

(ii) Beyond the on-site or off-site reconstruction model, all planning strategies should take the socio-economical context into consideration, and keep the local needs and developmental prospects in sight. In this perspective, top-down government action should not make expansion forecasts that are too optimistic. A well-grounded strategic program should be tailored to specific local priorities and potentialities, providing progressive scenarios based on productive activities and already-existing facilities.

(iii) The new cities should be planned on the old villages, avoiding the "new town model" as much as possible. Sustainable post-seismic reconstruction programs are increasingly required to interpret landscape signs and emergencies, setting up the new urban structure over the existing one and re-establishing the memory of a certain space as much as possible. The new city should resume the richness of the old village, in terms of mixed use, modulation of public spaces, articulation of the road system, and complexity of the urban fabric. This should make it possible to preserve the ancient path of the village, instead of founding a new town.

(iv) The on-site reconstruction itself does not mean "putting everything where and how it was" [49], reproducing the new village as an identical copy (but not authentic) compared to the destroyed one. By contrast, it includes an evaluation about social and territorial transformations occurring on the sites, where not everything has to be preserved [50]. In a semiological perspective, the reconstruction programs should also face the dialectics of preservation and innovation. This involves very complex evaluation, as widely debated within restoration theories, such as the construction of new buildings in ancient historical contexts. On the one hand, it involves reconstructing the image of the ancient villages where the inhabitants can recognize their own place identity. On the other hand, suitable spaces for contemporary life, which includes new technologies, should be provided for. In this perspective, the project could also introduce new elements according to the contemporary language of architecture, in a continuous interpretation process of the territory.

Finally, rather than repeating the slogan "where it was, how it was", we have to consider the city "how it will be", viewing the reconstruction as an opportunity to construct places for a future community.

Author Contributions: The general idea of this study has been developed by Matteo Clemente for the "17th CIRIAF National Congress-Energy-Environmental Sustainability and Seismic Retrofit of Built Heritage", 6-7 April 2017, Perugia, Italy and published in Italian language on the Proceedings of the Conference with the title "Paesaggi interrotti. Tra ricostruzione e identità dei luoghi". The paper has been improved and extensively reviewed equally by the two authors. Luca Salvati specifically reviewed and rewrite the discussion session.

Conflicts of Interest: The authors declare no conflict of interest. 


\section{References}

1. Guidoboni, E.; Valensise, G. (Eds.) L'Italia dei Disastri. Dati e Riflessioni Sull'impatto Degli Eventi Naturali 1861-2013; Bonomia University Press: Bologna, Italy, 2014; ISBN 8873959040.

2. Guidoboni, E.; Valensise, G. Il Peso Economico e Sociale dei Disastri Sismici in Italia Negli Ultimi 150 Anni [The Socio-Economic Burden of Seismic Disasters in Italy over the Last 150 Years]; Bononia University Press: Bologna, Italy, 2011; ISBN 9788873956839.

3. Bealt, J.; Mansouri, S.A. From disaster to development: A systematic review of community-driven humanitarian logistics. Disasters 2017. [CrossRef] [PubMed]

4. Casamento, A.; Guidoni, E. (Eds.) Le città ricostruite dopo il terremoto siciliano del 1693, tecniche e significati delle progettazioni urbane. In Storia Dell'urbanistica/Sicilia II; Edizioni Kappa: Roma, Italy, 1997.

5. Piazza, S. La ricostruzione difficile: Conflitti sociali e imprese architettoniche nel val di Noto dopo il terremoto del 1693. In Proceedings of the International Conference on Terremoti e Ricostruzioni tra XVII e XVIII Secolo, Noto, Italy, 24 October 2009; Edibook Giada: Palermo, Italy, 2012; pp. 23-28.

6. Triglia, L. Ricostruzione del Val di Noto Dopo il Terremoto del 1693; Gangemi: Roma, Italy, 1994; ISBN 9788874485963.

7. Maretto, P. Edificazioni Tardo Settecentesche Nella Calabria Meridionale; Teorema: Firenze, Italy, 1975.

8. Boschi, E.; Guidoboni, E.; Ferrari, G.; Mariotti, D.; Valensise, G.; Gasperini, P. Catalogue of Strong Italian Earthquakes from 461 B.C. to 1997. Annal. Geofis. 2000, 43, 609-868. [CrossRef]

9. Tacconi, G. Ricostruzione Post Sisma. Wolters Kluwer Ingegneri.info/Urbanistica. 2016. Available online: http:/ / www.ingegneri.info/news/urbanistica/ (accessed on 14 March 2017).

10. Aprile, M. Il terremoto del Belice o del fraintendimento. In La Furia di Poseidon: Messina 1908 e Dintorni; Campione, G., Ed.; Silvana: Milano, Italy, 2009; pp. 221-234.

11. Nicolìn, P. (Ed.) Dopo il Terremoto. In Quaderni di Lotus; Electa: Milano, Italy, 1983.

12. Scibilia, F. The reconstruction of Gibellina after the 1968 Belice Earthquake. In Proceedings of the International Planning History Society, Delft, The Netherlands, 17-21 July 2016; Volume 17.

13. Marinoni, G. Metamorfosi del Centro Urbano; Franco Angeli: Milano, Italy, 2004; ISBN 9788846464149.

14. Calvi, G.M.; Spaziante, V. La ricostruzione tra provvisorio e definitivo: Il Progetto C.A.S.E [The reconstruction between temporary and definitive: The C.A.S.E. Project]. Progettazione Sismica 2009, 3, 227-252.

15. Özerdem, A.; Rufini, G. L'Aquila's reconstruction challenges: Has Italy learned from its previous earthquake disasters? Disasters 2013, 37, 119-143. [CrossRef] [PubMed]

16. Alexander, D.E. The L'Aquila earthquake of 6 April 2009 and Italian Government policy on disaster response. J. Natl. Resour. Policy Res. 2010, 2, 325-342. [CrossRef]

17. Carnelli, F.; Forino, G.; Zizzari, S. L'Aquila 2009-2016. The earthquake in the Italian social sciences. Sociologia Urbana e Rurale 2016, 111-114. [CrossRef]

18. Hajek, A. Learning from L'Aquila: Grassroots mobilization in post-earthquake Emilia-Romagna. J. Mod. Ital. Stud. 2013, 18, 627-643. [CrossRef]

19. Contreras, D. Fuzzy Boundaries between Post-Disaster Phases: The Case of L'Aquila, Italy. Int. J. Disaster Risk Sci. 2016, 7, 277-292. [CrossRef]

20. Forino, G. Disaster recovery: Narrating the resilience process in the reconstruction of L'Aquila (Italy). Geogr. Tidsskr. Dan. J. Geogr. 2015, 115, 1-13. [CrossRef]

21. Fois, F.; Forino, G. The self-built ecovillage in L'Aquila, Italy: Community resilience as a grassroots response to environmental shock. Disasters 2014, 38, 719-739. [CrossRef] [PubMed]

22. Teti, V. New Town, Retoriche e Abbandoni. Dieci Anni Dopo la Frana di Cavallerizzo; Doppiozero: Milano, Italy, 2015; ISSN 2239-6004. Available online: http:/ / www.doppiozero.com/materiali/serjilla/new-townretoriche-e-abbandoni (accessed on 14 March 2017).

23. De Cunzo, M. La gestione dei piani di recupero. In Proceedings of the Conference: I Piani di Recupero nei Centri Storici, Rome, Italy, 12-14 November 1987; BEMA Editrice: Milano, Italy, 1988; pp. 47-50.

24. Miarelli Mariani, G. Legge 457: Licenza di distruggere. Restauro 1979, 41, 92-94.

25. Gambarotto, S. Il Terremoto in Friuli 6 Maggio 1976. Il Crollo e la Rinascita; Editoriale Programma: Treviso, Italy, 2016; ISBN 9788866434894.

26. Nimis, G.P. La Ricostruzione Possibile nel Centro Storico di Gemona del Friuli Dopo il Terremoto del 1976; Marsilio: Venezia, Italy, 1988; ISBN 8831750313. 
27. Bellina, A. L'anastilosi Nella Ricostruzione del Friuli; Arti Grafiche Friulane: Udina, Italy, 1988.

28. Manyena, S.B. The concept of resilience revisited. Disasters 2006, 30, 433-450. [CrossRef] [PubMed]

29. Mercer, J.; Kelman, I.; Lloyd, K.; Suchet-Pearson, S. Reflections on use of participatory research for disaster risk reduction. Area 2008, 40, 172-183. [CrossRef]

30. Imperiale, A.J.; Vanclay, F. Experiencing local community resilience in action: Learning from post-disaster communities. J. Rural Stud. 2016, 47, 204-219. [CrossRef]

31. Alexander, D.E. Resilience and disaster risk reduction: An etymological journey. Natl. Hazards Earth Syst. Sci. 2013, 13, 2707-2716. [CrossRef]

32. Lucini, B. Disaster Resilience from a Sociological Perspective: Exploring Three Italian Earthquakes as Models for Disaster Resilience Planning; Springer: London, UK, 2014; ISBN 978-3-319-04738-6.

33. Forino, G.; Ciccarelli, S.; Bonamici, S.; Perini, L.; Salvati, L. Developmental policies, long-term land-use changes and the way towards soil degradation: Evidence from Southern Italy. Scott. Geogr. J. 2015, 131, 123-140. [CrossRef]

34. Coles, E.; Buckle, P. Developing community resilience as a foundation for effective disaster recovery. Aust. J. Emerg. Manag. 2004, 19, 6-15.

35. Geipel, R. Long-Term Consequences of Disasters: The Reconstruction of Friuli, Italy, in Its International Context, 1976-1988; Springer: New York, NY, USA, 1991; ISBN 978-1-4612-3064-9.

36. Turri, E. Semiologia del Paesaggio Italiano; Longanesi: Milano, Italy, 1979; ISBN 9788830409606.

37. Hidalgo, M.C.; Hernàndez, B. Place attachment: Conceptual and empirical questions. J. Environ. Psychol. 2001, 21, 273-281. [CrossRef]

38. Tuan, Y.F. Topophilia: A Study of Environmental Perception, Attitudes and Values; Columbia University Press: New York, NY, USA, 1990; ISBN 9780231073950.

39. Gasparini, A. La Sociologia Degli Spazi. Luoghi, Città, Società; Carocci Editore: Roma, Italy, 2000; ISBN 9788843015436.

40. Frémont, A. Vi Piace la Geografia? Carocci: Roma, Italy, 2008; ISBN 978-8843043903.

41. Turri, E. Il Paesaggio Come Teatro: Dal Territorio Vissuto al Territorio Rappresentato; Marsilio: Venezia, Italy, 1998; ISBN 8831768654.

42. Andreotti, G. Geografia e cultura. In Geografia Culturale: Idee ed Esperienze; Andreotti, G., Salgaro, S., Eds.; Artimedia: Trento, Italy, 2001; pp. 55-68. ISBN 9788887980042.

43. Sciolla, L. Sociologia dei Processi Culturali; Il Mulino: Bologna, Italy, 2002; ISBN 8815239065.

44. Clemente, M. Smart Land and Resilient Districts. The resourece of cultural landscapes. In Resilient Districts. Post-Crisis Local Development and Sustainable Society; Salvati, L., Clemente, M., Eds.; Kappa: Roma, Italy, 2016; ISBN 9788865142509.

45. Sarewitz, D.; Pielke, R.; Keykhah, M. Vulnerability and risk: Some thoughts from a political and policy perspective. Risk Anal. 2003, 23, 805-810. [CrossRef] [PubMed]

46. Magnaghi, A. Il Progetto Locale; Bollati Boringhieri: Torino, Italy, 2000; ISBN 9788833921501.

47. Mattioli, W.; Mancini, L.D.; Portoghesi, L.; Corona, P. Biodiversity conservation and forest management: The case of the sweet chestnut coppice stands in central Italy. Plant Biosyst. 2016, 150, 592-600. [CrossRef]

48. Marchetti, M.; Vizzarri, M.; Lasserre, B.; Sallustio, L.; Tavone, A. Natural capital and bioeconomy: Challenges and opportunities for forestry. Ann. Silvic. Res. 2014, 38, 62-73. [CrossRef]

49. Carbonara, G. Avvicinamento al Restauro; Liguori: Napoli, Italy, 2002; ISBN 9788820723125.

50. Miarelli Mariani, G. Riflessioni su un vecchio tema. Il nuovo nella città storica. Restauro 2003, 164, 11-48.

(C) 2017 by the authors. Licensee MDPI, Basel, Switzerland. This article is an open access article distributed under the terms and conditions of the Creative Commons Attribution (CC BY) license (http://creativecommons.org/licenses/by/4.0/). 